\title{
Motor Games Effects on Learning to Spell Numbers in 5 to 6-Year-Old Pupils
}

\author{
Fares Dahech ${ }^{1}$, Nizar Guemri ${ }^{2}$, Liwa Masmoudi ${ }^{3}$, Nizar Souissi ${ }^{1}$ \\ ${ }^{1}$ Physical Activity, Sport and Health Research Unit (UR18JS01), National Sport Observatory, Tunis, Tunisia \\ ${ }^{2}$ Faculty of Medicine of Sfax, University of Sfax, Sfax, Tunisia \\ ${ }^{3}$ Research Laboratory: Education, Motricity, Sport and Health, EM2S, LR19JS01, University of Sfax, Sfax, Tunisia \\ Email: *fares.dahech@outlook.com
}

How to cite this paper: Dahech, F., Guemri, N., Masmoudi, L., \& Souissi, N. (2021). Motor Games Effects on Learning to Spell Numbers in 5 to 6-Year-Old Pupils. Creative Education, 12, 2471-2483. https://doi.org/10.4236/ce.2021.1210185

Received: September 16, 2021

Accepted: October 27, 2021

Published: October 30, 2021

Copyright (c) 2021 by author(s) and Scientific Research Publishing Inc. This work is licensed under the Creative Commons Attribution International License (CC BY 4.0).

http://creativecommons.org/licenses/by/4.0/

\begin{abstract}
The writing skills, which are crucial for learning in school, develop as the child gets older. They can be enhanced through various approaches. In this study, we aimed to examine the effects of motor games, which is a didactic approach, on learning how to spell Arabic numbers. Fifty-one pupils aged between 5 and 6 years old (age $=6.17 \pm 0.33$ years) took part in this study. They were divided into 3 different learning groups: 1 ) a control group that followed a classical learning (CG: $\mathrm{n}=17$ ) using visual and auditory modalities; 2) a second group that followed a multisensory learning modality (MSG: $\mathrm{n}=17$ ); and 3 ) a third group that followed a motor learning modality (MLG: $\mathrm{n}=17$ ). The digits spelling performances (from 0 to 9 in random orders) were assessed before and after 10 learning sessions. The retained parameters from the spelling test were the direction of the digits, the number of correct digits out of 10 , and the number of non-mirrored digits out of 8 . The results showed that the spelling test performance improved for all groups after the three learning modalities. However, the MLG showed the highest gains in plotting numbers performance $(7.06 \pm 1.25)$ compared to the CG $(0.65 \pm$ $2.32)$ and MSG $(2.41 \pm 2.15)(P<0.05)$. In addition, the other performance parameters displayed similar gains. These results suggest that the motor learning method is the most effective for improving numbers spelling, particularly for the digits spelling direction, compared to other learning methods.
\end{abstract}

\section{Keywords}

Sensorimotor, Spell, Digit, Teaching, Play, Child, Transfer

\section{Introduction}

Spelling is a complex activity that involves the acquisition of sensorimotor, in- 
tentional, cognitive, and linguistic skills at the same time (Viviani, 1994; Zesiger, 1995; Graham \& Weintraub, 1996; Bara et al., 2006, 2010, 2011; Bara et al., 2007). It also requires attention, simultaneous and sequential production, memorization capacity, and language mastery (Levine, 1987). Likewise, motor and everyday life activities constitute children's first language while motor skills are among the first essential literacy components. Thus, it is important to get children engaged in play (Dugas \& Point, 2012), which would naturally contribute to their emotional, sensory-motor, cognitive, intellectual, and social development (Gaussot, 2002). Overall, children learn more effectively when they can experiment, live, and manipulate (De Lièvre \& Staes, 2000). Consequently, motor learning has been implemented in pre- and primary schools to teach different subjects since it helps develop skills (Brougère, 2005; Wauters-Krings, 2009). In this context, several studies incorporated physical activities in the classroom in various areas of learning such as mathematics, history, art, music, or foreign languages (Mahar et al., 2006; Donnelly \& Lambourne, 2011; Kibbe et al., 2011; Mahar, 2011; Tarp et al., 2016). For example, it has been observed that integrating movement into the primary math curriculum is effective for improving the level of students (Riley et al., 2016; Singh et al., 2019) and for fun and engagement of children without compromising the quality of learning (Riley et al., 2017). Physical activity has also beneficial effects on physical health, mental and cognitive development (Institute of Medicine, 2013) and improves learning outcomes (Donnelly \& Lambourne, 2011). Through play, learners become active agents of their own learning unlike those sitting passively in traditional classrooms. Moreover, a study by the American National Research Council (2000) showed that learners find themselves emotionally engaged in the game, which helps them to imprint their actions and decisions into their memory. Thus, motor games could be effectively used to facilitate the learning of certain skills differently from traditional teaching methods (Federation of American Scientist, 2006; Mayo, 2007).

Likewise, previous works showed that pupils would engage more easily and would be more motivated to learn through situations that reconcile play and cognitive development (Kieff \& Casbergue, 2000; Krings, 2009; Marinova, 2011). In the child developmental approach "Motor actions must be understood as a product of cognitive development and at the same time as a source of development” (Lehalle \& Mellier, 2013). In this context, Adolph $(2005,2008)$ suggested that the child's cognitive development is associated with the acquisition of walking and other gross and fine motor skills. Moreover, previous works on the links between motor development and several cognitive skills confirmed the importance of motor skills in a theoretical approach like that of Piaget or in rehabilitation specific programs for children with coordination acquisition disorder (Geuze, 2005) or attention deficit hyperactivity disorder (Schilling et al., 2003). Recently, Pesce et al. (2019) has found important links between physical exercise and cognition as well as motor development and motor learning. 
The need for spelling preparatory exercises is well-established. In fact, De Ajuriaguerra and Augias (1960) emphasized the importance of developing children's motor abilities and perceptual skills so that they learn how to spell. They also stated that the educational environment must set up specific educational situations for the development of both sensory and motor skills. This educational approach aims at using the attractiveness and the commitment inherent in play to boost students' attention and engage them in learning (Dondlinger, 2007).

Physical activity seems to play an important role in the development of cognitive functions and, in particular, executive ones. Hence, the child whose motor skills have not reached a satisfactory state of development is likely to face learning difficulties from its earliest years of schooling (Connor-Kuntz \& Dummer, 1996). Thus, the development of motor skills in children through interactive motor education involving the construction of a positive self-image by integration into the group could remedy, in part, this problem.

This study aimed at assessing whether motor games, as a learning method, could improve the spelling of numbers and the motor development of the child given the fact that motor skills are important for learning, spelling acquisition, and thus, academic success. We hypothesized that learning based on motor skills could help children make fewer mistakes in the spelling of numbers. The motor modality in learning to write numbers could also allow children to encounter fewer difficulties during this apprenticeship.

\section{Methods}

\subsection{Participants}

Fifty-one Tunisian pupils (age $=6.17 \pm 0.33$ years) enrolled in the first year of primary education took part in this study after getting their parents' consent. They were divided into 3 experimental groups (Classical group: $\mathrm{n}=17$; age = $6.18 \pm 0.44$ years; body-mass $=27.6 \pm 4.4 \mathrm{~kg}$; height $=1.21 \pm 0.07 \mathrm{~m}$; Multisensory group: $\mathrm{n}=17$, age $=6.15 \pm 0.28$ years; body-mass $=26 \pm 3.4 \mathrm{~kg}$; height $=1.2$ $\pm 0.06 \mathrm{~m}$; Motor group: $\mathrm{n}=17$; age $=6.18 \pm 0.25$ years; body-mass $=28.6 \pm 6.1$ $\mathrm{kg}$; height $=1.23 \pm 0.06 \mathrm{~m}$ ) according to the following criteria: age, body-mass, height, and writing skills.

\subsection{Material and Procedure}

This study was carried out in 3 phases including the pre-test evaluations, the learning sessions, and the post-test assessments. During the pre-tests, the children were evaluated individually in order to obtain information about their writing skills. Then, in groups of 17, the students participated in 10 sessions lasting 20 minutes, at the rate of 2 sessions per week, during which they received the apprenticeship assigned to them, led by the teacher. Here is the description of each.

In classical learning, the session usually began with the discovery of the first digit. The teacher presented this figure to the children and made its outline, with 
the forefinger on the board in front of them. Next, the children reproduced this outline at least 5 times in the space; then on a table. Finally, they each wrote this outline on the slate at least 5 times using their pens. The same approach was adopted for all the presented digits (session 1: number 5, session 2: number 4, session 3: number 2, session 4: number 3, session 5: number 1, session 6: number 7, session 7: number 6, session 8: number 8 , session 9: number 9 , and session 10: number 0 ).

In multisensory learning, the session started with the presentation of the first digit to be studied. A card was used as support with a digit written in relief, in large. The children each received a copy of this card and were asked to explore it freely with their dominant hand. Then, the teacher made the outline of this digit in front of them, with the forefinger on the card. The students reproduced this outline at least 5 times. Eventually, blindfolded, the pupils had to reproduce the line of the digit on the card studied. The second digit studied was proceeded in the same way as the first one (in session 1, the number 5 was studied; in session 2 , the number 4 ; session 3 , the number 2 ; session 4 , the number 3 ; session 5 , the number 1 ; session 6 , the number 7 ; session 7 , the number 6 ; session 8 , the number, 8 ; session 9 , the number 9 , and the number 0 in session 10 ).

In motor learning, the session usually started with the presentation of the first digit studied, with a drawing on the ground, with a number drawn in large. Children were invited to explore it freely by walking on this digit. Then, the teacher followed the direction of the outline of this digit walking in front of them, and then the pupils imitated the teacher in at least 5 times. The same was done while playing with a wheel. Afterwards, blindfolded, the students had to reproduce the outline of the studied digit by walking and playing with the wheel. Finally, the second digit is proceeded with in the same way as the first (session 1: number 5, session 2: number 4, session 3: number 2, session 4: number 3, session 5: number 1, session 6: number 7, session 7: number 6, session 8: number 8 , session 9: number 9, and number 0: session 10).

The post-tests were identical to the pre-ones. For the pre- and post-tests, students were dictated numbers from 0 to 9 , one by one, in a random order, determined by a draw of cards face down. Each number was written on a different piece of paper. A point was awarded to each digit if the written digit is correct (recognizable, even if it is mirrored), a dot for the non-mirrored orientation of that digit, and a dot for the correct direction of the line.

\subsection{Data Analysis}

Statistical analysis of the data was performed using Statistica software (Statsoft, France). Data are presented as means and standard deviations in the text and as means and standard errors in the figures. The Shapiro-Wilk test has revealed that most of the studied variables were not normally distributed. Thus, non-parametric tests were used. The before-after learning comparison was performed by the Wilcoxon test. Kruskal Wallis' ANOVA was used to compare the progress 
(delta) of the three groups. Once the ANOVA showed a significant effect, MannWhitney tests were used to compare the methods (groups) two by two. The Chisquare (Khi-2) test was used to compare the percentages of progression, stagnation, or regression recorded for each group.

\section{Results}

\section{Number of correct digits (out of 10)}

Means of correct digits (out of 10) measured before and after the learning sessions for the three groups are shown in Figure 1.

The Wilcoxon test showed significant differences between before and after learning for the three experimental groups. On the other hand, Kruskal Wallis' ANOVA did not reveal any significant difference concerning the progresses (delta) of the three groups.

The percentages of pupils who showed progression, stagnation, or regression in the number of correct digits (out of 10) for the three groups are shown in Figure 2.

The Khi-2 test was not significant $\left(\mathrm{X}^{2}=8.01 ; \mathrm{p}=0.0911\right)$, which means that following the learning sessions, the three methods (groups) do not significantly differ in terms of the number of correct digits (out of 10).

\section{Number of digits not written in mirror (out of 8)}

Means of digits not written in mirror (out of 8) measured before and after the learning sessions for the three groups are shown in Figure 3.

The Wilcoxon test showed significant differences between before and after learning for the three experimental groups. Furthermore, the ANOVA of Kruskal Wallis did not display any significant difference between the progresses (delta) of the three groups.

The percentages of students who showed progression, stagnation, or regression in the number of digits not written in mirror (out of 8 ) for the three groups

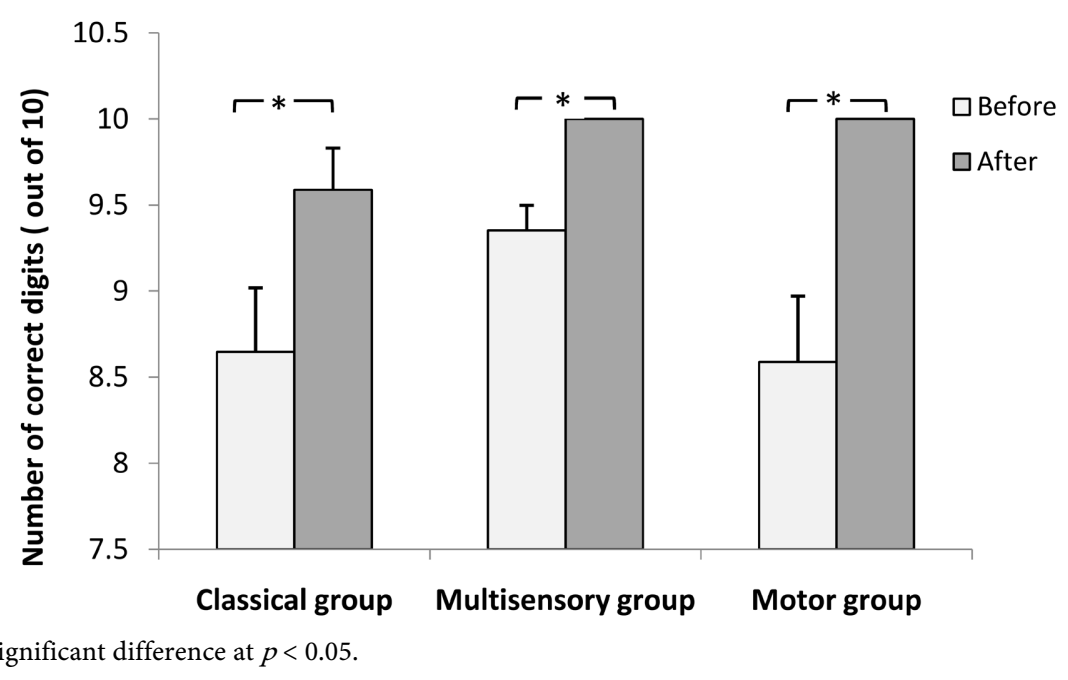

Figure 1. Number of correct digits (out of 10) recorded before and after the learning sessions for the three groups. 


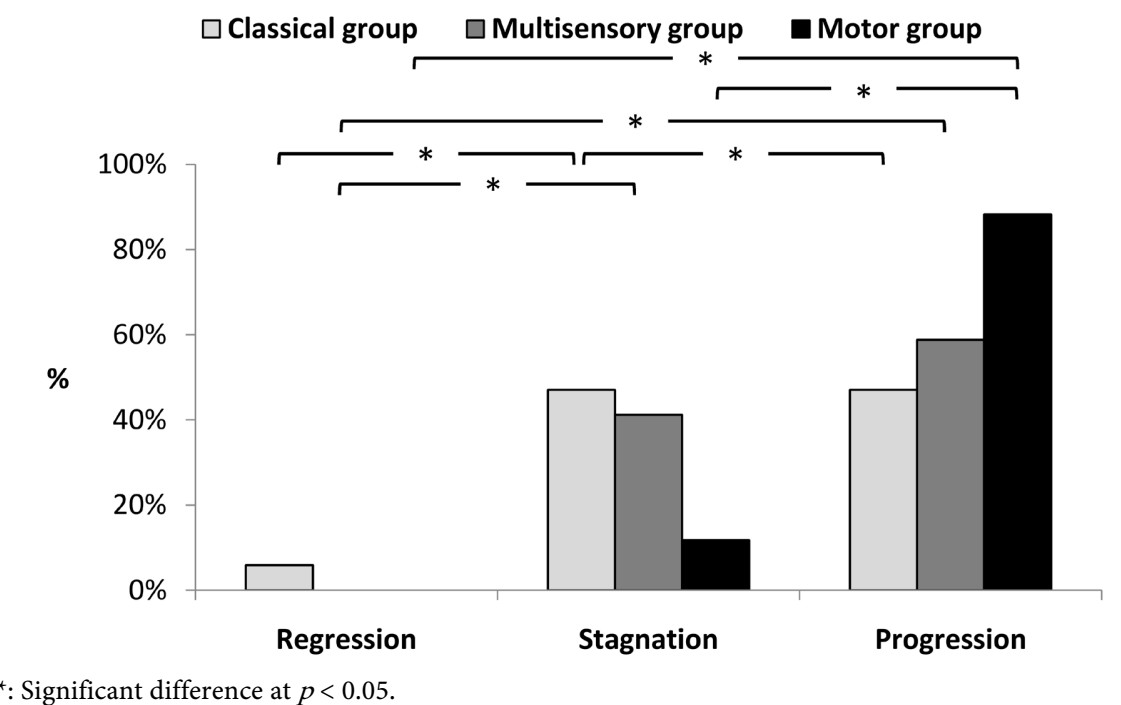

Figure 2. Percentages of students who showed progression, stagnation, or regression in the number of correct digits (out of 10) for the three groups.

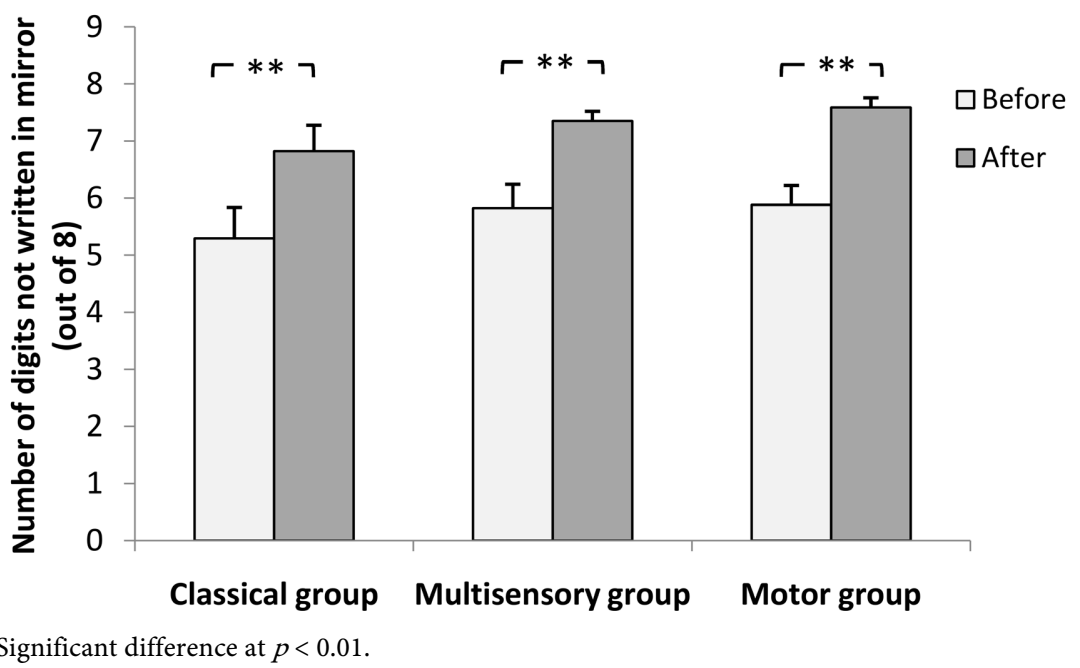

Figure 3. Number of digits not written in mirror (out of 8) recorded before and after the learning sessions for the three groups.

are presented in Figure 4.

The Khi-2 test was not significant $\left(\mathrm{X}^{2}=7.28 ; \mathrm{p}=0.1215\right)$, which means that following the learning sessions, the three methods (groups) do not significantly differ in terms of the number of digits not written in mirror (out of 8).

\section{Number of digits outlined in the correct direction (out of 10)}

Means of digits outlined in the correct direction (out of 10) measured before and after the learning sessions for the three groups are shown in Figure 5.

A significant change was observed for the multisensory and motor groups before and after the training, while the classical group did not show any remarkable modification. In addition, the ANOVA of Kruskal Wallis indicated how significantly effective is the method (group) for the progress achieved. Peer comparisons (Mann-Whitney test) revealed that the multisensory group showed 


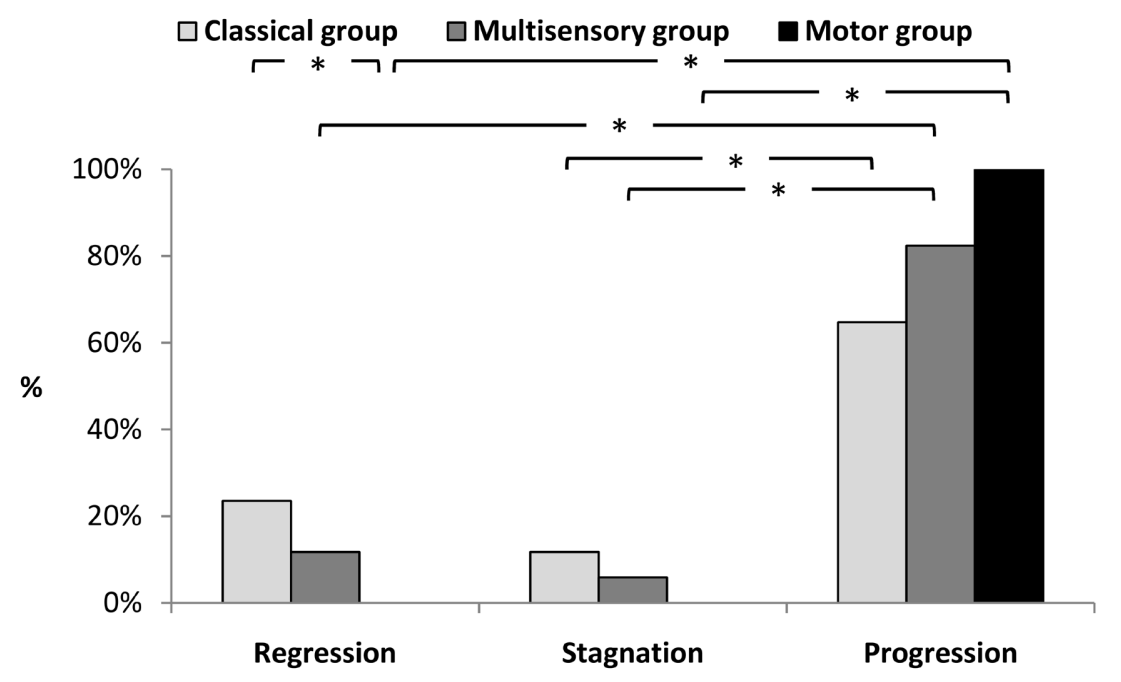

*: Significant difference at $p<0.05$.

Figure 4. Percentages of students who showed progression, stagnation, or regression in the number of digits not written in mirror (out of 8) for the three groups.

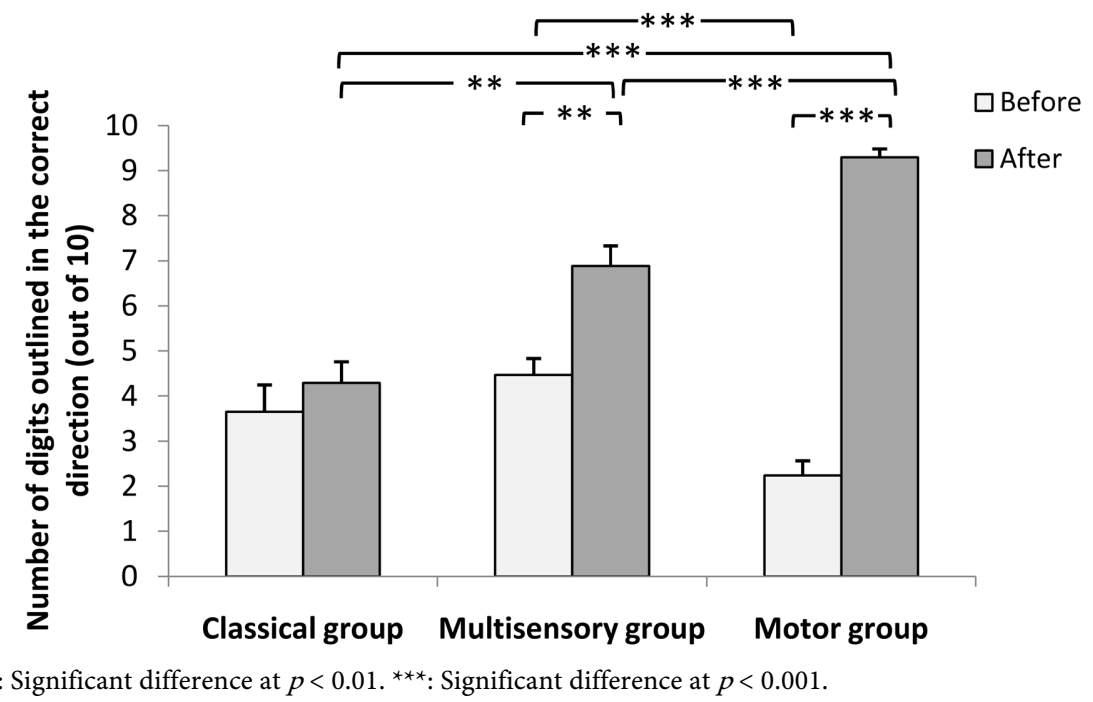

Figure 5. Number of digits outlined in the correct direction (out of 10) recorded before and after the learning sessions for the three groups.

statistically better progress than the classical group and that the motor group has made more progress than the two other groups.

The percentages of students who showed progression, stagnation, or regression in the number of correct digits (out of 10) for the three groups are shown in Figure 6.

The Khi-2 test was significant $\left(\mathrm{X}^{2}=14.23 ; p=0.0065\right)$, which shows the close relationship between learning and the method used. Peer comparisons showed that the percentage of students who made progression was notably higher than those who regressed and those who stagnated in both motor and multisensory groups. Furthermore, the percentage of students who regressed and those who stagnated in the classical group was significantly more important than in the 


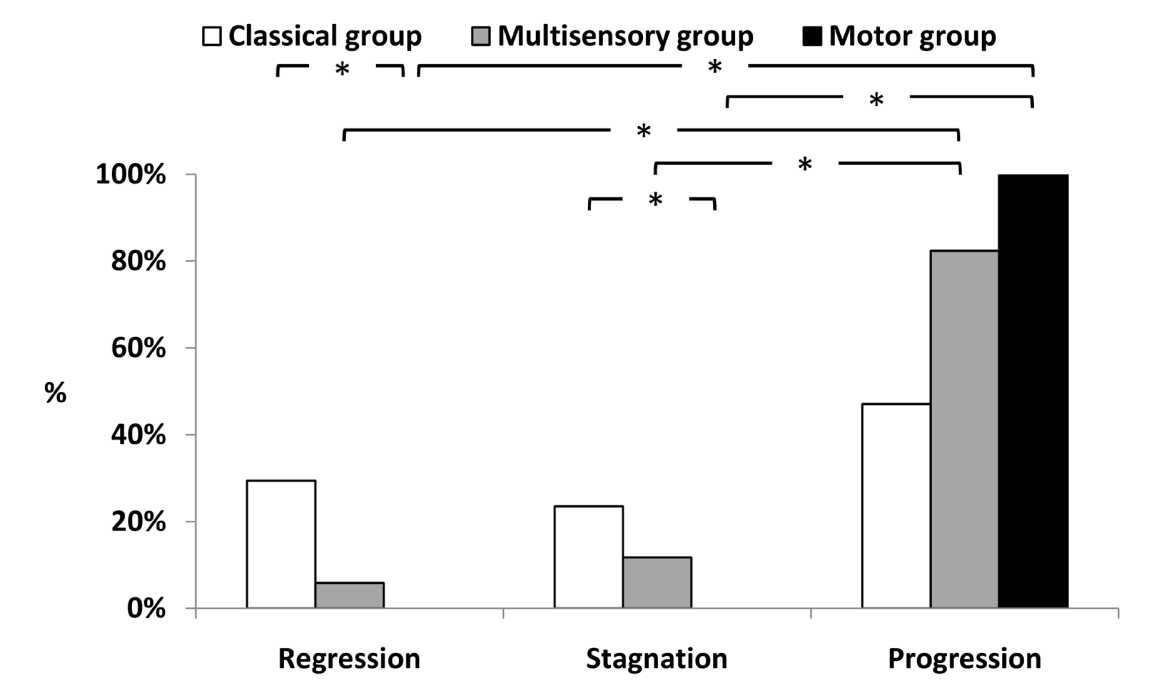

*: Significant difference at $p<0.05$.

Figure 6. Percentages of students who showed progression, stagnation, or regression in the number of digits outlined in the correct direction (out of 10) for the three groups.

motor group.

\section{Discussion}

The present study revealed that the use of the motor modality in learning to spell numbers from 0 to 9 helped 5 - 6-year-old students improve the outlines quality. Indeed, the pupils having explored the numbers with motor games made fewer errors in the outline direction of the numbers than the students in the classical and multisensory groups. These results conform to those of Gimbert et al. (2013) who indicated that the use of the haptic modality in training preparing for writing numbers from 0 to 9 enhanced 5 - 6-year-old children's outline quality. In fact, children who haptically explored the numbers made fewer errors in the digits outline direction than the children of the classical group.

In addition, the current study demonstrated that the students having received motor learning showed a better performance, mainly in the sense of the numbers outline, between the pre-test and the post-test, than the pupils having received classical and multisensory learning. These results suggest that motor learning modality can be effective in reducing mirror writing produced when learning to spell numbers. This supports the idea that motor learning allows children to form a mental image of what they are working on, which will help engrave it in their memory. So, memory is responsible for mirrored writing that does not depend on perception (Corballis \& Beale, 1976; Dehaene, 2007). Mirror writing can be observed during dictation while it is almost non-existent during a copying exercise (Fischer, 2011).

Moreover, students showed a significant progress between before and after learning for the three methods in terms of the number of non-mirrored digits as well as the correct dictated ones. However, all three groups witnessed almost similar progress, revealing that the motor modality addition did not bring any 
significant progress. Consistent with numerous studies, Ginsburg (2007) stated that play allows children to use their creativity while developing their imagination, dexterities, and physical aptitudes, as well as cognitive and emotional skills. Thus, motor games provide children with the experiences of movement and creativity as well as friendships in a context that promotes pleasure (Lester \& Russel, 2010). Other studies focused on the relationship between games and mathematics. In fact, games are effective teaching tools in boosting math performance (Lee et al., 2004; Kebritchi et al., 2010). Theorists (Beck et al., 2016; Riley et al., 2017) also suggested that motor and movement-based learning increase children's engagement, thus their performance in mathematics. In addition, several studies (e.g., Hardy et al., 2010; Riley et al., 2016) revealed that learning with the Encouraging Activity to Stimulate Young (EASY) Minds movement-based program is considerably beneficial thanks to the varied and interesting activities used in the lesson. Added to that, the EASY Minds lessons are more innovative, attractive, and enjoyable than the classical math lessons. Finally, the integration of this approach based on movement enables learners to examine perceptions and appreciate learning mathematics, increasing enjoyment and decreasing disengagement (Martin et al., 2012). On the other hand, the use of traditional approaches in mathematics has deepened learners' non-involvement and demotivation (Attard, 2013). Furthermore, play and other informal activities provide children with a convenient context in which they become interested in mathematics, develop their skills, and broaden their conceptual understanding (Ginsburg et al., 2008). So, learning through play can be enjoyable, motivating, and interesting for students (Papastergiou, 2009).

Therefore, the present study shows the effect of motor games on learning to write numbers by a transfer from practice to a cognitive activity. This transfer of learning, also called transfer of practice, proves to be fruitful in the majority of educational programs. Moreover, it is considered the ultimate goal of all effective education aimed at the development and the integral well-being of learners (Nokes-Malach, 2009; De Palma \& Ringer, 2011; Belenky \& Nokes-Malach, 2012; Lobato et al., 2012; Perkins \& Solomon, 2012; Larsen-Freeman, 2013).

\section{Conclusion}

The results of the present study showed that the use of motor games in spelling numbers improved the quality of their outline as a greater number of digits are written in the correct direction.

\section{Conflicts of Interest}

The authors declare no conflicts of interest regarding the publication of this paper.

\section{References}

Adolph, K. E. (2005). Learning to Learn in the Development of Action. In J. J. Rieser, J. J. 
Lockman, \& C. A. Nelson (Eds.), Action as an Organizer of Learning and Development: Vol. 33 in the Minnesota Symposium on Child Development (pp. 91-122). Lawrence Erlbaum Associates Publishers.

Adolph, K. E. (2008). Learning to Move. Current Directions in Psychological Science, 17, 213-218. https://doi.org/10.1111/j.1467-8721.2008.00577.x

Attard, C. (2013). “If I Had to Pick Ant Subject, It Wouldn't Be Maths”: Foundations for Engagement with Mathematics in the Middle Years. Mathematics Education Research Group, 25, 569-587. https://doi.org/10.1007/s13394-013-0081-8

Bara, F., Gentaz, E., \& Colé, P. (2006). Comment les enfants apprennent-ils à écrire et comment les aider. Apprentissages et Enseignement. Sciences Cognitives et Education, 9-24.

Bara, F., Gentaz, E., \& Colé, P. (2007). Haptics in Learning to Read with Children from Low Socio-Economic Status Families. British Journal of Developmental Psychology, 25, 643-663. https://doi.org/10.1348/026151007X186643

Bara, F., \& Gentaz, É. (2010). Apprendre à tracer les lettres: Une revue critique. Psychologie Française, 55, 129-144. https://doi.org/10.1016/j.psfr.2010.01.001

Bara, F., \& Gentaz, E. (2011). Haptics in Teaching Handwriting: The Role of Perceptual and Visuo-Motor Skills. Human Movement Science, 30, 745-759. https://doi.org/10.1016/j.humov.2010.05.015

Beck, M. M., Lind, R. R., Geertsen, S. S., Ritz, C., Lundbye-Jensen, J., \& Wienecke, J. (2016). Motor-Enriched Learning Activities Can Improve Mathematical Performance in Preadolescent Children. Frontiers in Human Neuroscience, 10, Article No. 645. https://doi.org/10.3389/fnhum.2016.00645

Belenky, D. M., \& Nokes-Malach, T. J. (2012). Motivation and Transfer: The Role of Mastery-Approach Goals in Preparation for Future Learning. Journal of the Learning Sciences, 21, 399-432. https://doi.org/10.1080/10508406.2011.651232

Brougère, G. (2005). Jouer/Apprendre. Economica-Anthropos.

Connor-Kuntz, F., \& Dummer, G. (1996). Teaching across the Curriculum: LanguageEnriched Physical Education for Preschool Children. Adapted Physical Activity Quarterly, 13, 302-315. https://doi.org/10.1123/apaq.13.3.302

Corballis, M. C., \& Beale, I. L. (1976). The Psychology of Left and Right. Routledge.

De Ajuriaguerra, J., \& Auzias, H. (1960). Méthodes et techniques d'apprentissage de l'écriture. La Psychiatrie de l'enfant, 3, 609. Presses Universitaires de France.

De Lièvre, B., \& Staes, L. (2000). La psychomotricité au service de l'enfant. De Boeck Belin.

De Palma, M. J., \& Ringer, J. M. (2011). Toward a Theory of Adaptive Transfer: Expanding Disciplinary Discussions of Transfer in Second-Language Writing and Composition Studies. Journal of Second Language Writing, 20, 134-147. https://doi.org/10.1016/j.jslw.2011.02.003

Dehaene, S. (2007). Neurones de la lecture (Les): La nouvelle science de la lecture et de son apprentissage. Odile jacob.

Dondlinger, M. J. (2007). Educational Video Game Design: A Review of the Literature. Journal of Applied Educational Technology, 4, 21-31.

Donnelly, J. E., \& Lambourne, K. (2011). Classroom-Based Physical Activity, Cognition, and Academic Achievement. Preventive Medicine, 52, S36-S42.

https://doi.org/10.1016/j.ypmed.2011.01.021

Dugas, C., \& Point, M. (2012). Portrait du développement moteur et de l'activité physique 
au Québec chez les enfants de 0 à 9 ans. Rapport de l'Université du Québec à Trois-Rivières, Québec.

Federation of American Scientist (2006). R\&D Challenges in Games for Learning (p. 17). Federation of American Scientist.

Fischer, J. P. (2011). Nouveaux éclairages sur l'écriture en miroir des enfants de l'école maternelle. Revue Française de Pédagogie, 2, 99-112.

Gaussot, L. (2002). Le jeu de l'enfant et la construction sociale de la réalité. Spirale, 4, 39-51. https://doi.org/10.3917/spi.024.0039

Geuze, R. H. (2005). Postural Control in Children with Developmental Coordination Disorder. Neural Plasticity, 12, Article ID: 831549. https://doi.org/10.1155/NP.2005.183

Gimbert, F., Gentaz, É., \& Mazens, K. (2013). Évaluation d'entraînements multisensoriels de préparation aux apprentissages numériques chez les enfants scolarisés en grande section de maternelle. Approche neuropsychologique des apprentissages chez l'enfant No. 123, 189-196.

Ginsburg, H. P., Lee, J. S., \& Boyd, J. S. (2008). Mathematics Education for Young Children: What It Is and How to Promote It. Social Policy Report, 22, 1-24. https://doi.org/10.1002/j.2379-3988.2008.tb00054.x

Ginsburg, K. R. (2007). The Importance of Play in Promoting Healthy Child Development and Maintaining Strong Parent-Child Bonds. Pediatrics, 119, 182-191.

https://doi.org/10.1542/peds.2006-2697

Graham, S., \& Weintraub, N. (1996). A Review of Handwriting Research: Progress and Prospects from 1980 to 1994. Educational Psychology Review, 8, 7-87. https://doi.org/10.1007/BF01761831

Hardy, L. L., King, L., Espinel, P., Cosgrove, P., \& Bauman, C. (2010). NSW Schools Physical Activity and Nutrition Survey (SPANS) Full Report. NSW Ministry of Health.

Institute of Medicine (2013). Identifying and Addressing the Needs of Adolescents and Young Adults with Cancer. The National Academies Press.

Kebritchi, M., Hirumi, A., \& Bai, H. (2010). The Effects of Modern Mathematics Computer Games on Mathematics Achievement and Class Motivation. Computers \& Education, 55, 427-443. https://doi.org/10.1016/j.compedu.2010.02.007

Kibbe, D. L., Hackett, J., Hurley, M., McFarland, A., Schubert, K. G., Schultz, A., \& Harris, S. (2011). Ten Years of TAKE 10! : Integrating Physical Activity with Academic Concepts in Elementary School Classrooms. Preventive Medicine, 52, S43-S50. https://doi.org/10.1016/j.ypmed.2011.01.025

Kieff, J. E., \& Casbergue, R. M. (2000). Playful Learning and Teaching: Integrating Play into Preschool and Primary Programs. Allyn \& Bacon.

Krings, F. (2009). Les jeux à l'école: Chimère culturelle ou réalité? Union des Fédérations des Associations de Parents de l'Enseignement Catholique, 5, 8-15.

Larsen-Freeman, D. (2013). Transfer of Learning Transformed. Language Learning, 63, 107129. https://doi.org/10.1111/j.1467-9922.2012.00740.x

Lee, J., Luchini, K., Michael, B., Norris, C., \& Soloway, E. (2004). More than Just Fun and Games: Assessing the Value of Educational Video Games in the Classroom. CHI'04: EXtended Abstracts on Human Factors in Computing Systems, Vienna, 24-29 April 2004, 1375-1378. https://doi.org/10.1145/985921.986068

Lehalle, H., \& Mellier, D. (2013). Psychologie du développement: Enfance et adolescence (3e éd.). Dunod.

Lester, S., \& Russell, W. (2010). Children's Right to Play: An Examination of the Importance of Play in the Lives of Children Worldwide. Bernard van Leer Foundation. 
Levine, R. D. (1987). Molecular Reaction Dynamics and Chemical Reactivity. Oxford University Press.

Lobato, J., Rhodehamel, B., \& Hohensee, C. (2012). "Noticing” as an Alternative Transfer of Learning Process. Journal of the Learning Sciences, 21, 433-482. https://doi.org/10.1080/10508406.2012.682189

Mahar, M. T, Murphy, S. K, Rowe, D. A., Golden, J., Shields, A. T., \& Raedeke, T. D. (2006). Effects of a Classroom-Based Program on Physical Activity and On-Task Behavior. Medicine and Science in Sports and Exercise, 38, 2086-2094. https://doi.org/10.1249/01.mss.0000235359.16685.a3

Mahar, M. T. (2011). Impact of Short Bouts of Physical Activity on Attention-to-Task in Elementary School Children. Preventive Medicine, 52, S60-S64. https://doi.org/10.1016/j.ypmed.2011.01.026

Marinova, K. (2011). Jeu et apprentissage au préscolaire. Québec Français, No. 162, 64-65.

Martin, A. J., Anderson, J., Bobis, J., \& Way, J. (2012). Switching On and Switching Off in Mathematics: An Ecological Study of Future Intent and Disengagement among Middle School Students. Journal of Educational Psychology, 104, 1-18. https://doi.org/10.1037/a0025988

Mayo, M. J. (2007). Games for Science and Engineering Education. Communications of the ACM, 50, 30-35. https://doi.org/10.1145/1272516.1272536

National Research Council (2000). How People Learn: Brain, Mind, Experience, and School: Expanded Edition (384 p). The National Academies Press.

Nokes-Malach, T. J. (2009). Mechanisms of Knowledge Transfer. Thinking and Reasoning, 15, 1-36. https://doi.org/10.1080/13546780802490186

Papastergiou, M. (2009). Exploring the Potential of Computer and Video Games for Health and Physical Education: A Literature Review. Computers \& Education, 53, 603-622. https://doi.org/10.1016/j.compedu.2009.04.001

Perkins, D. N., \& Salomon, G. (2012). Knowledge to Go: A Motivational and Dispositional View of Transfer. Educational Psychologist, 47, 248-258. https://doi.org/10.1080/00461520.2012.693354

Pesce, C., Croce, R., Ben-Soussan, T. D., Vazou, S., McCullick, B., Tomporowski, P. D., \& Horvat, M. (2019). Variability of Practice as an Interface between Motor and Cognitive Development. International Journal of Sport and Exercise Psychology, 17, 133-152. https://doi.org/10.1080/1612197X.2016.1223421

Riley, N., Lubans, D. R., Holmes, K., \& Morgan, P. J. (2016). Findings from the EASY Minds Cluster Randomized Controlled Trial: Evaluation of a Physical Activity Integration Program for Mathematics in Primary Schools. Journal of Physical Activity and Health, 13, 198-206. https://doi.org/10.1123/jpah.2015-0046

Riley, N., Lubans, D. R., Holmes, K., Hansen, V., Gore, J., \& Morgan, P. J. (2017). Movement-Based Mathematics: Enjoyment and Engagement without Compromising Learning through the EASY Minds Program. Eurasia Journal of Mathematics, Science and Technology Education, 13, 1653-1673. https://doi.org/10.12973/eurasia.2017.00690a

Schilling, D. L., Washingtoin, K., Billingsley, F. F., \& Deitz, J. (2003). Classroom Seating for Children with Attention Deficit Hyperactivity Disorder: Therapy Balls versus Chairs. The American Journal of Occupational Therapy, 57, 534-541. https://doi.org/10.5014/ajot.57.5.534

Singh, A. S., Saliasi, E., Van Den Berg, V., Uijtdewilligen, L., De Groot, R. H., Jolles, J., Ericsson, I. et al. (2019). Effects of Physical Activity Interventions on Cognitive and Academic Performance in Children and Adolescents: A Novel Combination of a Systemat- 
ic Review and Recommendations from an Expert Panel. British Journal of Sports Medicine, 53, 640-647. https://doi.org/10.1136/bjsports-2017-098136

Tarp, J., Domazet, S. L., Froberg, K., Hillman, C. H., Andersen, L. B., \& Bugge, A. (2016). Effectiveness of a School-Based Physical Activity Intervention on Cognitive Performance in Danish Adolescents: LCoMotion-Learning, Cognition and Motion-A Cluster Randomized Controlled Trial. PLoS ONE, 11, Article ID: e0158087. https://doi.org/10.1371/journal.pone.0158087

Viviani, P. (1994). Les habiletés motrices.

Wauters-Krings, F. (2009). Psychomotricité à l'école maternelle. Les situations motrices au service du développement de l'enfant. De Boeck.

Zesiger, P. (1995). Écrire: Approches cognitive, neuropsychologique et développementale. Presses universitaires de France. 